\title{
Metaphors in English for economics: for a language-based approach with L2 learners
}

Catherine Resche

\section{OpenEdition}

\section{Journals}

\section{Electronic version}

URL: http://journals.openedition.org/asp/1984

DOI: 10.4000/asp.1984

ISBN: 978-2-8218-0384-8

ISSN: 2108-6354

\section{Publisher}

Groupe d'étude et de recherche en anglais de spécialité

\section{Printed version}

Date of publication: 1 October 2001

Number of pages: $239-259$

ISSN: 1246-8185

\section{Electronic reference}

Catherine Resche, «Metaphors in English for economics: for a language-based approach with L2 learners », ASp [Online], 31-33 | 2001, Online since 22 November 2010, connection on 30 April 2019 URL : http://journals.openedition.org/asp/1984; DOI : 10.4000/asp.1984

This text was automatically generated on 30 April 2019

Tous droits réservés 


\title{
Metaphors in English for economics: for a language-based approach with L2 learners
}

\author{
Catherine Resche
}

1 So many researchers have already investigated the field of metaphors that it is always an ambitious and challenging undertaking to write yet another research paper on the subject. Therefore, we have chosen to clearly limit our scope to English for Specific Purposes and more precisely to the language of economics from the angle of applied linguistics. Our goal is to observe and "to understand underlying processes of language learning or use" (Cameron 1999a: 3) and here, we are concerned with studying how to help foreign learners of English for economics by focusing on the interrelations between form and content in metaphors. In other words, we are not only interested in metaphors as vehicles for learning and understanding concepts but we also mean to consider them as bridges between concepts and their linguistic expression through appropriate, authentic wording. In this respect, and especially when we keep in mind our L2 approach, lexical items, collocates, phrases need to be studied more systematically in order to make it easier for foreign learners to identify, understand, and eventually re-use the numerous metaphors that are an essential constituent of the language of economics.

Obviously, before illustrating the need to insist on a lexical, phrase-oriented approach with a view to ensuring a better command of metaphors in a foreign specific language, it is necessary to have a closer look at the functions and types of metaphors encountered in economics and to consider various instances of discourse in order to identify where the real difficulties lie. Accordingly, the present paper starts with a review of our sources in order to explain how our corpus was compiled. Then, the functions and characteristics of the most current metaphors are analysed and the necessary links between conceptual frames and lexical networks are underlined. Finally, the relevance of a language-centred approach is discussed in the context of foreign-language acquisition in the field of ESP. 


\section{Sources and selection of the corpus}

English for specific purposes is still too often caricatured as limited to a list of technical terms, which evidences blindness to the 'E' in ESP, i.e., failure to understand that any specialised language is, in essence, a language, deeply-rooted in the general language. English for economics is no exception. As a specific language, it has obviously given birth to its own technical terms, and it will sometimes be selective when it borrows words from general English - giving priority to some collocates over others - but the interaction between English for economics and general English cannot be denied. Thus, as metaphors are part and parcel of our everyday language, they are also a constitutive element of the language of economics and have to be taken into consideration and included in its study.

Our basic preoccupation in selecting our corpus was to take into account a range of sources that would be large enough to allow comparisons across genres (Swales 1991). It seemed to us that a logical starting point for our investigation was to refer to the writings and the theories of famous economists (Adam Smith, John Maynard Keynes, to name but a few) whose contribution to the 'dismal science' is widely-acknowledged. We shall see that the metaphors they used are of special interest, and that they confirm that metaphors are not ignored by the scientific community. Our second source of data consisted of the writings of contemporary economics professors and researchers such as Paul Samuelson (1998), Robert Barro (1994) and N. Gregory Mankiw (1998) who combine theoretical research and pedagogical concerns: their articles and their widely-read economics textbooks proved very useful. In addition to the academic spheres, we felt it wise to investigate the language of economists in decision-making positions such as central bankers and M. Alan Greenspan, as well as former Federal Reserve chairmen, who offered interesting insights into metaphors. Finally, the economic press - Financial Times, The Wall Street Journal, The Economist, Business Week - appeared as a useful complement to the other sources, enabling us to assess whether and to what extent metaphors vary according to the target public.

It would be unrealistic and dishonest to pretend that the set of metaphors we have gathered from our sources offers an exhaustive account of the metaphors produced and used in the language of economics. Keeping our L2 learners in mind, we have made a point of not overcrowding our lists with isolated, punctual metaphors. Rather, we have focused on and only retained only the recurring metaphors that emerged from the figurative seams of data we have mined across genres, i.e., those metaphors that have to be mastered by anybody wishing to improve their command of the language of economics. This should not be taken to mean that the same metaphors are used in the same invariable way. On the contrary, we have paid special attention to the variations on a number of themes and to the underpinning lexical variations they entail. L2 learners need to be made aware of the fact that freedom of choice is only apparent as the range of equivalents that can be used is constrained by the language itself and by convention. Their approach to metaphors in ESP has to take such restraints into account. 


\section{The functions of metaphors in the language of economics}

6 Ortony (1979: 3) underlines that "any serious study of metaphor is almost obliged to start with the works of Aristotle". It would be vain to follow this piece of advice just for the sake of guaranteeing the seriousness of this paper or with a view to merely respecting the rules. Nevertheless, if we choose to refer to Aristotle, it is because it will help us to clarify our standpoint. As this study is explicitly concerned with ESP, it stands to reason that we are not dealing with metaphors in literature. Our focus is neither poetry nor tragedy, but prose within the context of a social science. In this respect, Aristotle's Rhetoric, in its approach to prose, seems to be better suited to our purpose than his analysis of metaphor in Poetics. Indeed, his insistence on the great creative ability required from the epic poets or tragedians in order to produce good metaphors appears to be irrelevant to the metaphors in our corpus. Yet Aristotle's interest in the ubiquity of metaphors in everyday discourse, as expressed in Rhetoric, allows a distinction between the art of creating new metaphors and the mere ability to use ready-made metaphors. Our phrase-centred, lexical approach aimed at L2 learners is of course well-served by the latter aspect. Obviously, our aim is not to teach them to coin new metaphors but just to help them identify and understand recurring metaphors, and enrich their stock of lexical items in the process. Ultimately, they should be able to include the conventional metaphors in their own discourse on economic matters. After pointing out that everyone uses metaphors in conversation, Aristotle underlines the cognitive value of metaphors and stresses their pedagogical role. To him, good metaphors are lucid and they give people a clearer, more vivid and more concise explanation of facts, relations and notions than plain, literal language.

7 We now turn to the language of economics in order to bring evidence of these various functions of metaphors. To this end, let us consider the most widely-known metaphor in economics, that of the 'Invisible Hand', coined by Adam Smith in his 1776 book, The Wealth of Nations. Actually, this particular metaphor epitomises different aspects of the role of metaphors insofar as it first appeared both to introduce, support and explain the theory of the market mechanism. In other words, it filled a lexical gap in an efficient way, illustrating the catachrestic use of metaphor:

Every individual endeavours to employ his capital so that its produce may be of greatest value. He generally neither intends to promote the public interest, nor knows how much he is promoting it. He intends only his own security, only his own gain. And he is in this led by an 'invisible hand' to promote an end which was no part of his intention. By pursuing his own interest, he frequently promotes that of society more effectively than when he really intends to promote it. (Samuelson 1998: 29)

8 Under such circumstances, the invisible hand metaphor can be considered to have helped the researcher himself to frame his new concept and shape his ideas. Only in a second time does it serve as a simplified means of conveying the notion to others. Indeed, the cognitive value encompasses the concept-forming as well as the consciousness-raising aspects. The latter function consists in "inviting interaction by forcing [the learner] to work out the relevant resemblance between target and source domains" (Cortazzi \& Jin 1999: 161). As for the pedagogical aspect, it is closely related to the notion that metaphors help to simplify complex or abstract notions and to memorise them more easily by 
organising concepts into systems (Lakoff \& Johnson 1980). The invisible hand metaphor now a basic notion for any student in economics - is abundantly quoted and exploited in economic textbooks (Samuelson 1998: 30, 200-201; Mankiw 1998: 150, 199, 216, 421, 530).

Two other examples point to how convenient it is to refer to a whole theory by using the conventional coded metaphors. The first is the Random Walk, which refers to the erratic price movements of stocks. "A price follows a random walk when its movements over time are completely unpredictable" (Samuelson 1998: 487). As "in an efficient market all predictable things have already been built into the price, it is the arrival of new information [...] that affects stock or commodity prices". The second example deals with capital flows and, through the metaphor of the Herd Effect, it describes the massive speculative inflows and outflows of capital triggered by the decision of a leader whose reaction influences a host of followers. In both cases, once the metaphors have been understood, they are immediately associated with the underpinning theories. Such "theory-constitutive scientific metaphors become [...] the property of the entire scientific community" (Boyd 1979: 362). As there is no need to explicitly return to the theoretical foundation, the result is a gain of time and words.

Precisely, this third function of metaphor, i.e., concision, is directly related to our lexical approach since the necessary condition for making a long story short is to choose the most appropriate term that will convey the desired idea and act as a linchpin for the metaphor. We have chosen a more recent source to illustrate this point because it does not require any particular background in economics. In a lunchtime lecture delivered by Nick Elam, British Ambassador to Luxembourg, the speaker describes a customer's arrangements with his bank in the following two ways. The first example does not contain any metaphor and requires seventy-four words to explain the situation:

I have persuaded my bank to adopt a device whereby they hold most of my cash assets on deposit in an interest bearing account and move money from this account to my current account as and when the latter falls below an agreed minimum balance, and restore money to the deposit account when the current account exceeds the balance. This enables me to maximise the interest earned on liquid assets without going into overdraft.

11 With a metaphor, the same story can be reduced to twenty-four words: "My bank has agreed to siphon money between my deposit account and my current account when needed, to give me maximum interest without overdrawing". The magic lies in the suggestive power of 'siphoning', which helps to simplify the message by describing money in terms of plumbing. This confirms the function of metaphor as a great and swift aid to communicate notions and ideas, provided understanding is not hampered by unknown lexical items.

To underline how economical some of the metaphors in economics can be, we would like to end this section with two illustrations from economics textbooks - both connected with 'inflation'. The first one concerns 'shoe leather costs', which can be explained very simply. Since inflation erodes the real value in our wallets, the point is to keep more of our wealth on interest-bearing savings accounts and less in our wallets. This, of course, implies more frequent trips to the bank, hence the metaphoric phrase. As Mankiw points out:

The actual cost of reducing your money holding is not the wear and tear on your shoes but the time and convenience you must sacrifice to keep less money on hand than you would if there were no inflation. (1998: 625) 
Another consequence of inflation is the price-adjustment costs for firms, called 'menu costs'. The term is derived from a restaurant's cost of printing new menus, but it applies to all sorts of firms having to decide on new prices, to print catalogues, to advertise the new prices, to send the new price lists, etc. As we can see, the two metaphoric phrases dealing with costs are unlikely to pose any problem to L2 learners, once their meanings have been cleared. Actually, they are short, simple, easy to remember and to re-use. Above all, they are set phrases. Other kinds of metaphors are more complex and therefore more difficult to grasp, as we shall see now.

\section{The characteristics of metaphors in the language of economics}

\subsection{Extinct or active metaphors?}

14 Like any language, English for economics contains a number of terms with metaphoric origins that have become so common that they seem to have lost their figurative potential, at least to the eyes of most users. If we consider terms like inflation, growth, floating rates, or an economic slowdown, we may well be tempted to conclude that the italicised words have lost their original meaning and that in all these terms, the metaphors are dead or extinct. However, a closer analysis of our corpus suggests how hasty such a conclusion might be. We have already claimed in another study on currencies and metaphors (Resche 1998: 72) that the term 'dormant' would be more appropriate insofar as such metaphors retain some productive vitality which can be reactivated at any time (Black 1979: 26), as illustrated in the following examples.

When taken literally, 'inflation' calls forth images of swelling, of a balloon or a bubble and new life can easily be breathed into the dormant metaphor by systematically exploiting its potential. This is precisely where difficulties may arise for L2 learners. Following a logical evolution, it is natural to conceive of a bubble swelling to such a point that it will 'burst' on its own, producing a 'bang', unless someone gently 'lets some air out'. If 'pricked' with 'a pin', it will 'pop', etc. In another context, that of 'growth', the metaphor 'creaking at the seams' can only be understood after the reader has come to realise that growth also refers to an increase in physical size. If we now focus on 'slowdown' in 'an economic slowdown', and relate it to the notion of reduced speed, then we can better investigate its metaphoric potential. 'Speed limit' will logically come to mind, as well as all that can be done to reduce speed, i.e., 'braking' or 'hitting the brakes', or 'cutting off the fuel', as in the following contexts:

If American workers produce more per person, then the economy's safe speed limit rises. (The Economist, May 22, 1999: 59, "Return of the Dread-I?")

Still, steering the U.S. economy is always tricky. Greenspan knows that well from his experience in 1994 and 1995, when he hit the brakes to bring growth down to sustainable rates. (Business Week, November 8, 1999, "Can the Fed Hit its Mark?")

A pronounced slowdown in the high-tech sector [...] would cut off the fuel for the New Economy growth-and-productivity machine. (Business Week, July 12, 1999: 33)

These contexts evidence the potential associations with a vehicle ('steering'), a machine, an engine, a mechanism, and with all the connected phrases that can then be applied to the economy. The resulting metaphors combine to build a dense network that will be discussed later in this paper. What we wish to underline here is the specific approach 
required by a public for whom English is a second language. Once the literal meaning has been evidenced, they will no doubt be receptive to the metaphoric expansions which we have just mentioned. However, acquiring a command of the resulting metaphors so as to be able to re-use them is quite another matter for L2 students. Therefore, they need to be guided methodically on the lexical and structural paths, warned against the pitfalls of the language itself and taught to respect its constraints. Identifying, understanding and reusing metaphors also means being conscious of the various syntactic forms they can take.

\subsection{The syntactic forms of metaphors}

17 In spite of the fact that it is convenient to organise a number of metaphors with common surface traits under a generic metaphor of the type A is B (Lakoff and Johnson 1980), it would be a hasty conclusion to consider that metaphors where both topics and vehicles have nominal forms are the most representative kind. Understandably, if we have adopted this convenient method to structure the metaphors in our corpus into domains, fields, and sub-fields, it was to give a clearer view of the whole and to group them along thematic lines (Appendix 1). And it is true that a few metaphors in our corpus do echo the A is B syntax:

The flow of money is the lifeblood of our system.

Money is the lubricant of exchange.

Labour is the father of product and land the mother.

However, such examples were essentially found in textbooks, as pedagogical devices, and these nominal metaphors are actually rather exceptional in our corpus. In contrast, the metaphoric discourse we have examined evidences a wide range of syntactic forms, where verbal and prepositional metaphors play an important role.

The metaphors inspired by 'bubble' are a case in point. In many instances, the metaphor hinges on the verb and obviously, special attention has to be paid to the verbal collocates, in order to ensure that their use is fully mastered. For example, the verb 'swell' will be used with bubble as a subject, while 'puncture' and 'prick' only accept bubble as an object. However, 'inflate', 'deflate', 'burst' and 'pop' work both ways: 'the bubble pops', or 'something pops the bubble'. In addition, remarks about the corresponding noun forms need to be made: 'a prick' is correct as in 'As a bubble swells, an ever smaller prick is capable of popping it'. As for prepositional phrases, they also deserve attention for a nonnative public: 'to let the air out of the bubble' (not *off the bubble, not *away from the bubble, in case learners should be tempted to express this idea in a word-for-word translation). Understandably, in the context of foreign language acquisition, it is vital to underline such points.

In the same way, L2 learners have to be trained to identify metaphors with different lengths and constructions. Word metaphors like 'growth' or 'liquidity', can help to establish connections with phrase metaphors such as 'pools of liquidity', 'to be awash with liquidity', 'to mop up liquidity', 'to drain liquidity from the market', etc... Once the 'liquid' metaphor has become familiar, further associations and complex sentence metaphors of the following type can then logically be approached more easily:

In this increasingly foggy world, the chances of navigational errors are high. But even in the shorter term, the seas ahead could get much rougher [...] the best way for the navigators to stay afloat is to keep a wider watch for hazards at sea. (The Economist, September 25, 1999: 4-5, "Survey") 


\subsection{Co-textual and contextual metaphors} us to consider it as a metaphor, except for the fact that it is an economic text and not a maritime one. Ricoeur (1975: 110) reminds us that a statement is said to be metaphoric when some of its terms focus our attention for precisely being used metaphorically while others are not. This is, he insists, what differentiates a metaphor from a proverb, an allegory or an enigma, where all the terms are used metaphorically. Steen (1999: 84) refers to the type of metaphor illustrated above as 'implicit metaphors'. In such metaphors, 'the referent is not expressed in the same clause'. This requires the reader's ability to look for the other part of the metaphor - i.e. the topic - in a separate clause: the navigation metaphor needs to be considered in the general context of the article, which deals with the central bankers' difficult task of steering the economy and making the wisest possible choices.

The presence of the referent somewhere in the text leads Steen to call such metaphors 'co-textual' as opposed to 'contextual' metaphors, where the referent is not even present in the text, but has to be inferred from other contexts or from experience, as is partially the case in the following illustration:

Goldilocks is in danger of burning her tongue and the Fed may come to regret that

it did not raise interest rates sooner. (The Economist, September 25, 1999: 10,

"Survey")

The difficulty here lies in the fact that the reader may not at once understand the first part of the sentence, even though the context clearly focuses on economic matters. Indeed, the missing link that is at the origin of the 'Goldilocks metaphor' cannot be found in the context but has to be inferred from other sources. Goldilocks first has to be associated with the children's tale about the little girl who, once in the house of the bears, has to constantly look for the right-sized chair, plate, bed - neither too big nor too small, just right. Once the source has been identified, it needs to be considered in the context of a potentially overheating economy, resulting from a combination of such factors as fast growth, high consumer spending and low unemployment. Only then can the parallel be drawn between the risk for Goldilocks to burn her tongue if the porridge is too hot and the risks for a red-hot economy to get out of control.

In such metaphors, the responsibility of establishing coherence by referring to other encounters of the same metaphoric stock lies entirely with the reader. It is easy to imagine the increased difficulty of such a task for foreign learners. However, in the present case, Goldilocks has now become a ubiquitous metaphor - whether in the press or in the official speeches of the Federal Reserve authorities. Whenever 'the New Economy paradigm' is being discussed, mention of Goldilocks can surely be expected, which proves that trends also exist in both economic texts and the world of metaphors.

\subsection{Extended metaphors and systematicity}

As we pointed out when questioning the notion of dead metaphors, the term 'dormant' seems to be more appropriate as it suggests that there is scope for new extensions. The resulting metaphors can then give rise to networks which can operate either within a same text or across texts. Cameron (1999b: 129) refers to the extended metaphor at the 
level of a single text as 'local systematicity' while 'global systematicity' describes systems of metaphors occurring across texts, from a range of discourse types and content'. In the following excerpt from a recent article, a common thread can be found, although - to use the received terminology without any intention to play on words - the surface 'vehicles' may vary:

Although the economy continues to expand at a rapid clip, associates say that the Fed chief seems confident that the central bank's carefully calibrated policy mix and continuing productivity improvements have put the economy on the path to a soft landing. [...] For now Greenspan appears to be convinced that his patented blend of incrementalism has put the economy on the glide path to slower growth. [...] in 1994 and 1995 [...], the Fed wound up doubling short-term interest rates in the space of a year. That produced more of a touch-and-go landing. The economy quickly regained altitude in '96 and then soared, having unloaded its inflationary baggage, thanks to the Fed's tightening. This time, Greenspan can anticipate $a$ smoother ride [...] So will it be a soft landing? Despite the daft economic management to date, remember to keep your seat belts securely fastened until the economy taxis safely to the gate. (Business Week, November 8, 1999, "Can the Fed Hit its Mark?")

In this context, the economy is first identified with a plane through the 'soft landing' metaphor. The reader is then given more information about the kind of plane described here: a glider ('glide path'). Further down, the soft landing is being questioned and a 'touch-and-go landing' seems more likely. At the same time, the glider is transformed into a hot air balloon, able to 'regain altitude', provided it 'unloads' some of its 'baggage'. Then, the 'soft landing' can again be hoped for, but, this time, it is clearly combined with the image of a plane that 'taxis to the gate'. This allows to include the usual recommendation that the 'seatbelts' be 'securely fastened'. The different metaphors in this text are interrelated and they form a constructed network pertaining to our experience of flying in an aeroplane. Various metaphors on the same theme can be found in other texts so that it is also possible to consider much larger networks and to speak of global systematicity.

After a nasty bout of turbulence, a more gentle ride is in store. The world economy is reaching cruising altitude. As investors sit back, relax, and enjoy the ride, the big question to ponder is whether the jet-powered US economy is heading for a soft landing or not [...]. The OECD has now switched off the seat belt sign. Alan Greenspan, Fed chairman, is an experienced captain. His job is to raise rates to slow the economy from its pace of 4 per cent growth, which even the most ardent new paradigm advocate would admit is too fast. But he needs to do so in a way that does not cause a destabilising reaction in the equity, bond or foreign markets. If he pulls it off, he will deserve a round of applause in the cabin. (Financial Times, Nov.20, 1999, "Comments and Analyses")

However, we should not overlook the existence of commonly used phrases such as 'soaring prices' and 'skyrocketing costs' that seem to have paved the way for such a metaphoric field. More generally speaking, the economy is described in turn as a vehicle (a car, a train) as well as a ship, and each of these metaphors can generate a network of its own. This results in a very intricate system, with bigger branches and smaller ones, somewhat like a tree. Pepper (1935) chose the phrase 'root metaphors' to describe the metaphors reflecting deeper reasoning patterns and offering a wide range of creative opportunities - within the boundaries of the language, understandably. They could also be described as 'parent metaphors'.

Systematicity can also be field-specific as is the case when dealing with currencies. Whenever currency fluctuations are mentioned, the 'liquid' element will surface: it could 
be called 'the sea - storm - safe haven - rising tide metaphor'. As 'a rising tide lifts all boats', it is important to find a safe haven when caught in a storm at sea. Likewise, investors had better seek a 'safe haven currency' when a major currency crisis threatens to 'rock' the system. Another telling example of this type of systematicity is the field of monetary and fiscal policy. A central bank's task was once described by a former Fed official, William McChesney Martin as follows: “The Federal Reserve's job is to take away the punch bowl just as the party gets going" (Mankiw 1998: 723)

In his textbook, Samuelson (1998:625) reported the quotation slightly differently, changing the end into 'when the party was getting lively'. The same metaphoric quotation is echoed in the press, this time with both a literal explanation and a metaphoric extension:

William McChesney Martin, Governor of the Fed in 1951-70, memorably described the Fed's job as being "to take away the punch bowl just when the party is getting going, i.e., before the economy overheats and pushes up inflation. [...] The longer the party continues, the worse the eventual hangover. (The Economist, September 25, 1999: 16, "Survey")

A parallel can be drawn with Business Week's account of the same metaphor:

Greenspan is well aware that the Fed needs to take away the punch bowl when the party starts getting too fun [...] He has already started siphoning off some of the joy juice. (October 4, 1999: 35)

It is interesting to compare the different wording across genres, but what is striking is that we are now dealing with a metaphor with a universal status, systematically resorted to when broaching the issue of an overheating economy. Although it was a punctual creation, a casual remark, unlike Adam Smith's carefully chosen 'Invisible Hand', it has now been widely adopted by the community and integrated in the language of economics. Precisely, famous economists do not always resort to metaphors to support a theory, but just to add more weight to a statement or comment, or to illustrate a point more clearly. Just a few years before he wrote his General Theory of Employment, Interest and Money, Keynes chose the 'liquid' metaphor, coupled with a metaphor inspired by the natural elements, to criticise the way some economists give priority to the long term and tend to neglect the short term:

The long run is a misleading guide to current affairs. In the long run, we are all dead. Economists set themselves too easy, too useless a task if in tempestuous seasons , they can only tell us when the storm is long past, the ocean will be flat. (Mankiw 1998: 703)

This particular combination of metaphors is omnipresent in the language of economics, and is applied whenever a crisis is at stake, whether it is currency turmoil or a stock market crisis. The 'liquid metaphor', it is worth noting, was illustrated in a very peculiar way by Mr Bill Phillips - well-known for the Phillips curve - after a study published in 1958, in which he asserted that there was a trade-off between inflation and unemployment. An economist from New Zealand based at the London School of Economics, Mr Phillips was also a trained engineer, which led him to construct a machine with pipes, pumps and siphons to demonstrate the workings of the economy, using water to represent liquidity. Interestingly, he gave the 'liquid metaphor' a visible, concrete illustration. In the same register, Okun's 'leaky bucket' metaphor meant to characterise our distributive system of taxes and transfers is made ample use of:

The bucket of redistribution has developed a large leak [...] When all the leaks are added up, how big are they?... (Samuelson 1998: 355) 
Obviously, the last three examples are different from Adam Smith's metaphor in that they open the way for variations and, in this respect, may give rise to extensions that could be more difficult to understand than a simple phrase, set once and for all, like 'the invisible hand'.

\section{How relevant is a linguistic approach to metaphors in English for economics?}

\subsection{Notional and lexical networks}

Identifying root metaphors undeniably helps to clarify the links between the various metaphors and the related notions. In order to visualise such links, we have organised a number of metaphors mentioned in the course of this study into a network. In Appendix 2 , the notions are linked by arrows showing that when a particular semantic feature or 'seme' is emphasised in a given term, it is enough to conjure up another term, which explains how a same term can branch out in different directions. Our starting point was the notion of the economy as a vehicle with an engine. Immediately 'vehicle' generates road, air, or sea transport. Since we have already dealt with the metaphor of the plane through one of our examples, we will focus on 'ships' for our present discussion. A ship can hardly cross the 'seas' without being confronted with the elements, caught in a 'storm'. The likely outcomes are that she will 'keep afloat', 'drift' or 'sink'... If we now concentrate on the 'engine' metaphor, it is logically connected with such notions as 'fuel', 'spark', 'ignition', risks of 'overheating', 'stalling' or 'exploding'. 'Overheating' branches out on 'hot air', a 'balloon' or 'bubble', 'to inflate' and brings us back to the risk of 'explosion'. But if we extend the notion of overheating in another direction, we are led to consider 'temperatures' ranging from 'red-hot' to 'cool' and 'cold'. Now, if overheating is caused by 'speed', 'cooling off requires 'slowing down'. A different interpretation of 'temperature' may introduce medical metaphors, implying 'fever', 'sickness', 'contagion', 'remedies', 'medicine', and of course, 'recovery' and 'good health'. A sick 'patient', or a 'failing engine', require careful 'monitoring' in order to 'remedy' the problems. This can be achieved by 'keeping one's eyes on a screen' or a 'radar', or 'scanning the horizon' in order to 'avoid navigational errors'. It can also help to take good care of the 'mechanisms' by resorting to an 'injection' or 'oiling the wheels' with a 'lubricant', using the appropriate 'instruments' or 'tools' in the process...

Once such a network is clearly organised and the links identified and accepted, the hard task as far as L2 learners are concerned still remains to be learnt. The difficulty does not lie in the organisation of the notions, but in feeling comfortable with the corresponding lexical fields. This approach, however, should not consist in simply listing the different types of metaphors under the main terms identified in the notional network. What is required, rather, is a scrupulous observation and analysis of the constraints of the source and target languages. The students will have to be guided around the numerous pitfalls through a systematic focus on a number of linguistic problems, as illustrated in the next sections. 


\subsection{Semantic relations} downplaying others, which enables the creator, user or observer to relate this term - the vehicle - to the topic. This, obviously, takes for granted the fact that the reader will understand the link and be able to isolate the precise semantic feature that was selected. A native speaker or reader will have no trouble doing so, while a foreign learner may find it more difficult, especially if $s($ he) is not aware of the range of meanings contained in a specific lexical item. Focusing on polysemy will prove helpful in such cases. Let us consider the noun 'charge' to illustrate this point. Two of its meanings are likely to be familiar: in legal language, 'a formal accusation' and, in the economic sphere, 'an amount of money somebody is asked to pay for something they have bought or received'. In the field of banking, for example, the notion of interest charged by banks on loans will be known to students of economics who have already encountered it in the course of their studies in English. However, they risk being misled by the following context at first sight:

Foreign institutional investors' charges in and out of countries are highly correlated and have become more so over the past 5 years. (The Economist, August 21, 1999: 64, "Going with the Flow")

Because of the economic context, the first notion that will come to their minds may be an equivalent for 'fees' or 'taxes'. Only when they have connected 'charges' with the 'herd instinct' mentioned a few lines earlier in the text will they be able to fully grasp the metaphoric content.

Another aspect worth mentioning concerns the parallels which can be drawn between non-figurative and figurative senses of words. The question that should be raised is whether the lexical relations of antonymy for example are maintained once the terms are used metaphorically (Deignan 1999: 190). Our corpus fails to provide a clear answer to this problem. In some cases, the same pairs exist, whether the terms are taken literally or not. For example, a 'healthy' economy can be opposed to a 'sick' economy or an 'ailing' economy; a 'smooth 'crossing is the contrary of a 'rough' crossing when dealing both with a real ship and with the economy viewed as a ship. Yet, even though a native speaker will have no difficulty using the appropriate terms, a non-native speaker may rightly hesitate in some cases. Indeed, it is confusing to realise that, when combined with 'a ride', the opposite of ' a smooth ride' in the metaphors is rather 'a bumpy ride'. In the same way, when referring to the 'landing' of the economy, neither 'smooth' nor 'rough' will do, but the conventional metaphoric phrases will be 'a soft landing' and a 'hard landing', therefore logically leading to the notion of 'cushioning' the shocks in a hard landing. In other words, depending on the context and the collocates, a same adjective may have different opposites. A foreign learner may be disconcerted by this type of arbitrary pairs and will need to be made aware of them in order to avoid approximation, misuse or even confusion. Our corpus also evidences cases where the traditional pairs of opposites no longer apply in the metaphoric language of economics. The contrary of a 'liquid market' will neither be a 'solid' or 'rigid' nor a 'dry' market, but an 'illiquid market'. Again the conventional use of the latter adjective has to be underlined and prescribed if students are to apprehend the special use of a specific purpose language fully.

If L2 students are to be guided on the lexical and semantic paths with ever greater rigour, it is also because, even when they have become familiar with a particular metaphoric 
field, they are not immune to misunderstandings and misuse. Within a same field, lexical items may well apparently share traits and yet have altogether different meanings. Such is the case with 'fluctuation', 'flows', 'to keep afloat' and 'flotation'. 'Currency fluctuations' describe the ups and downs of currencies, the swings in their values on the foreign exchange market, while 'flows' refer to capital movements in and out of markets. As for 'keeping afloat', it can apply to a company that manages to 'keep its head above water', financially speaking, whereas a 'flotation' deals with a company's opening of its capital to the public, in other words, an initial public offering. None of this can obviously be left to mere guesswork.

In order to give a better idea of the need to stress the converging and diverging meanings of terms according to whether they are used literally or figuratively, we would like to consider the temperature register. In plain English, 'hot' is usually opposed to 'cold', and 'warm' to 'cool'. We have mentioned the metaphoric use of 'hot' when applied to the economy, but more information is necessary if students are to re-use the metaphors appropriately. Indeed, it is important to underline that the economy is never described as 'cold'. Yet, the hot economy will often have to 'cool down'. In other words, 'hot' is opposed to 'cool', and 'heating' or 'overheating' calls for 'cooling off' or 'chilling':

After all, the purpose of a rate hike is to cool an overheated economy. But an oil-price rise alone tends to do just that. It chills the economy because it diverts consumption spending offshore, to foreign oil producers [...] Raising rates would exacerbate the chilling effect of costly oil. (Business Week, Oct. 11, 1999: 40-41, "Who's Afraid of Pricey Oil?")

'Hot', however, has a different meaning as a conventional collocate for 'money'. In that case, 'hot money' is an equivalent for 'speculative money', i.e. money that flows in and out of markets, seeking the highest profits. Here again, it is worth stressing that when money is not speculative, it cannot be described as *cold money'. Yet, recently, an interesting example of how the literal meaning of 'hot' could be revived was provided by a commentator. Arguing that institutional investors could not be blamed entirely for financial crises, he wrote the following conclusion:

The study looked at several financial crises during the past five years and found that, in most of them, foreign institutions did not in fact pull out large amounts of money. Institutional money is lukewarm, not hot. (The Economist, Aug. 21 ${ }^{\text {st }}$, 1999: 64)

41 Though, as we have pointed out, awareness of the semantic relations between the terms is necessary and sometimes vital, it is not sufficient to help L2 learners to overcome the obstacles inherent in a metaphoric language. Syntactic problems also have to be dealt with.

\subsection{Focus on syntax}

Precisely, for a public of L2 students of economics, it is not the technical terms, or even the notions themselves that will pose problems - as they already have some background in the field in their own language - but rather all that is specific to the linguistic aspects and related to second language acquisition. Thus, as regards metaphors, the notional links do not represent so much of an obstacle as the various lexical and structural aspects of English, since metaphors require leaving the sphere of economics proper and venturing into the territory of general English and some of its unfamiliar areas. 

Nothing can be left to chance in this respect and only observation and practice will favour spontaneous use: indeed, it is troubling to have to say 'to keep inflation at bay' when equivalent, non metaphoric phrases based on the same verb are 'to keep inflation under control', or 'in check'. Careful scrutiny is also required as regards the parts of speech that are given priority in the metaphoric language and L2 students should be warned that transfers are not automatically acceptable. On this particular point, the following metaphor is interesting insofar as it gives us information on the possible choice between the verb 'to inject' and the corresponding noun form 'injection':

The Fed could inject some money into the economy by buying some government bonds from the public in open-market operations. What happens after such a monetary injection? (Mankiw 1998: 613)

But such alternatives are not systematic, as Low notes (1988: 131). If we consider another field, it is true that the verb 'to ignite' is conventionally used with 'inflation' as an object, but this does not allow us to conclude that the noun form 'ignition' can be automatically substituted as in 'the *ignition of inflation'. Actually, nowhere have we found such an occurrence to date. Discipline and respect for the genuine forms and phrases are therefore absolutely necessary if $\mathrm{L} 2$ learners are to be given the means to re-use some of the most frequent metaphors in the language of economics properly.

\subsection{Focus on collocates}

would now like to draw attention to the fact that some of the difficulties L2 learners have to face may well be connected with too limited a stock of common terms. Consequently, even though they may understand the general framework of a metaphoric field, they lack the conventional phrases that are the keys to understanding and re-using the metaphors and that make all the difference between approximate and genuine language.

Let us concentrate on the metaphoric developments around the field of mergers and acquisitions. The richest seams appear to be the registers of a union or marriage if things go smoothly and those of a battle or war in case of a hostile or unfriendly take-over bid. Accordingly, such registers are going to be fully exploited as sources for extended metaphors. All this seems very simple provided one is familiar with the terminology of the field. In the context of 'romance', this does not only include verbs like 'to court', 'to flirt', 'to woo', but phrases like 'a well-endowed suitor', 'to make it to the altar', 'the bridesmaid and groom', 'to tie the knot', 'would-be brides', 'the pairing up' and, in some cases, 'the white knight'...

Other cultural registers may have to be taken into consideration: 'a mating dance', 'a marriage of convenience', 'a marriage of blue bloods', 'to consummate a marriage'... In case the relationship should 'sour', other linguistic tools may prove necessary: 'to part', 'to divorce'... The latter situation may serve as a link between the metaphor of marriage or divorce and that of war and conflict, in which case, new terms are required: 'bloodletting', 'bloodshed', 'survivors', 'an arch-rival', 'a bidding war', not to mention 'poison pills'. The likelihood of branching out on the register of hunting cannot be excluded and such terms as 'a target', 'a prey', 'the hunter', 'the hunted'... should not be neglected. Merging also means getting bigger, which will open a whole, new register: 'behemoths', 'big beasts', 'couplings', etc. The same is true for other fields: when the 
economy's health is at stake, the medical register is naturally resorted to and then, again, the conventional associations of verbs and nouns have to be respected by the L2 learners: 'to prescribe treatment/medicine', 'to administer medicine', 'to diagnose a patient's condition'...

The great variety of the potential metaphoric fields does demand a wide range of lexical tools, all of which may not be familiar to the learners. As we have noticed from our experience with L2 students, in many cases, it is not so much the deep, conceptual meaning of the metaphor that is difficult to grasp as its surface, linguistic expression. A phrase-centred approach aimed at providing the learners with a richer lexical background can only help them to feel more comfortable with the metaphoric language.

\subsection{Results and limits of our experimentation}

Understandably, the linguistic approach cannot be restricted to one or two ESL/ESP courses and must be conceived as a longer-term process. For this reason, we could not resolve to divide our group of students into two parts, making one sub-group aware of metaphors through this approach and leaving the other students to their own devices. We felt it would not have been fair. Consequently, it is difficult for us to assess the impact of our approach exactly and in this respect, our experimentation is limited. However, we have some indication of how the students have integrated the metaphoric dimension in their own written language, both spontaneously, and when tested more concretely. By spontaneous use, we refer to essays, or analyses written by students, and in which common metaphors are used here and there, resulting in richer, more authentic usage. It can be argued that they were influenced by the remarks made verbally in the course of the English class, but no explicit recommendation was given for their papers.

As for the test, it was not focused on metaphors, but in one part, they were just innocently asked to explain 'the bond market is drowning in a sea of new issues'. Out of 42 students, 37 were able to come up with a relevant or elegant explanation. Among these, 28 resorted to another metaphor, and 8 rephrased the idea in plain English. The metaphoric answers were divided between 'the bond market is flooded with new issues' (20) and 'there is a glut of new issues on the bond market' (12). As appears from these figures, 4 students gave both answers. What was striking was that a greater number of students opted for the 'liquid metaphor', so as to remain in the same register. To be honest, this test was given only after weeks of awareness-raising to metaphors, once the students had become familiar with various registers, with the possible links that tied them into larger networks, and after they had become conscious of the need to acquire the proper linguistic tools before venturing to re-use metaphors.

On the whole, our linguistic focus on metaphors in English for economics seems to have had positive results and we have been able to notice how attractive an aspect of the language it can be for most students, even for those who are not so fluent, as if it revived their interest for a language they may have been studying for years and added confidence in the potential progress they can make. We have also observed how easy it is for students to memorise the recurring metaphoric phrases, once they have become conscious of the logical notional links and been given the means to enrich and improve their English in this field. As we pointed out all along this study, they cannot be expected to create their own extended metaphors, or even to re-use that type of metaphor, but at least to apprehend them. What this approach can do for them, though, is to train them to 
re-use and adopt the conventional metaphoric phrases that are part and parcel of the language of economics.

\section{Conclusion}

In this paper, we have deliberately considered the problem of metaphor from the angle of non-native learners of English for economics. We have tried to show how pervasive metaphors are by analysing their different functions in several types of economic discourse. Identifying the various types of word-, phrase- and sentence metaphors has led us to point out the specific difficulties with which L2 learners are confronted. We have established that the obstacles that they have to overcome are mostly of a lexical, semantic and grammatical nature, which is why we feel that metaphors in ESP in the context of second-language acquisition require a language-based approach.

Sensitisation to root and dormant metaphors is a means of drawing attention to the potential expansions in various directions on notional, semantic and lexical bases. In the case of extended metaphors, we have insisted that L2 learners can only be guided towards understanding - and not re-using or coining such metaphors. Obviously, too broad a stock of lexical items is at stake here for the students to aim at anything but passive recognition in this respect. However, as regards word- and phrase metaphors of the kind that permeate economic discourse across genres, active knowledge, i.e. acquisition and re-use are to be encouraged. It is vital for L2 learners to be trained to identify, understand and adopt such metaphors if they are to achieve greater authenticity in their use of English for economics. A language-based approach, as our experience has shown, can help to come closer to this goal and we would go so far as to say that there is a real and urgent need for the ongoing development of phrase books of metaphors in the field of ESP for L2 students.

\section{BIBLIOGRAPHY}

Aristotle. 1961. Rhétorique, Translated by Dufour. Paris: Les Belles Lettres.

Barro, R. J. and V. Grilli. 1994. European Macroeconomics. London: Macmillan.

Black, M. 1979. "More about metaphor". In Ortony, A. (ed.), Metaphor and Thought. Cambridge:

Cambridge University Press, 19-43.

Boyd, R. 1979. "Metaphor and theory change: What is 'metaphor' a metaphor for?". In Ortony, A. (ed.), Metaphor and Thought. Cambridge: Cambridge University Press, 356-408.

Cameron, L. 1999a. “Operationalising 'metaphor' for applied linguistic research”. In Cameron, L. and G. Low (eds.), Researching and Applying Metaphor. Cambridge: Cambridge University Press, 3-28. 
Cameron, L. 1999b. "Identifying and describing metaphors in spoken discourse data". In Cameron, L. and G. Low (eds.), Researching and Applying Metaphor. Cambridge: Cambridge University Press, 105-132.

Cortazzi, M. and L. Jin. 1999. "Bridges to learning: Metaphors of teaching, learning and language". In Cameron, L. and G. Low (eds.), Researching and Applying Metaphor. Cambridge: Cambridge University Press, 149-176.

Deignan, A. 1999. “Corpus-based research into metaphor”. In Cameron, L. and G. Low (eds.), Researching and Applying Metaphor. Cambridge: Cambridge University Press, 177-199.

Elam, N. 1998. FOG Lunchtime Lecture, <http://europa.eu.int/comm/sdt/en/ftfog/elam.htm>. Lakoff, G. and M. Johnson. 1980. Metaphors We Live By. Chicago, IL: Chicago University Press. Low, G. D. 1988. “On teaching metaphor”. Applied Linguistics 9/2, 125-147.

Mankiw, N. G. 1998. Principles of Economics. Fort Worth, TX: Harcourt College Publishers. Ortony, A. 1979. “Metaphor: A multidisciplinary problem”. In Ortony, A. (ed.), Metaphor and Thought. Cambridge: Cambridge University Press, 1-22.

Pepper, S. 1935. “The root metaphor theory of metaphysics”. Journal of Philosophy 32, 365-374.

Resche, C. 1998. “Discours métaphorique et monnaies: les particularités de l'euro". ASp 19-22, 67-88.

Ricoeur, P. 1975. La métaphore vive. Paris: Éditions du Seuil.

Samuelson, P. A. and W. D. Nordhaus. 1998. Economics, $16^{\text {th }}$ edition. Boston, MA: McGraw-Hill.

Steen, G. 1999. "Metaphor and discourse". In Cameron, L. and G. Low (eds.), Researching and Applying Metaphor. Cambridge: Cambridge University Press, 81-104.

Swales, J. M. 1990. Genre Analysis. Cambridge: Cambridge University Press.

\section{APPENDIXES}

\section{Appendix 1}

\section{BALLOON/BUBBLE: INFLATION}

Air: 'to let the air gently out of the bubble' (The Economist)

Burst: 'An explosive bursting of the American bubble' (The Economist)

Froth/Frothy/Frothiness: 'It took some of the froth out of Wall Street, if only momentarily. The Dow dove on April 27, to 8917.' (The Wall Street Journal)

Inflate: 'to prevent a bubble from inflating' (Financial Times)

Pin: 'Mr Greenspan is still the man with the pin' (The Wall Street Journal)

Pop/Bang: 'The bigger a bubble gets, the bigger the bang when it eventually pops' (The

Economist)

Prick/Swell: 'As a bubble swells, an ever smaller prick is capable of popping it' (Time)

Puncture: 'Most central bankers, particularly those at the Fed, are hostile to the idea of trying to puncture bubbles.' (The Economist)

BEAST: INFLATION IS A WILD ANIMAL

Beast/Escape/Recapture: 'If the beast of inflation escapes, the increase in interest rates needed to recapture it will then have to be bigger' (The Wall Street Journal) 
Cage: 'Why was the United States able to put the inflationary tiger in the cage, while Russia failed to do so?' (Samuelson)

Galloping/Rein in: 'To rein in a galloping equity market' (Financial Times)

Tame: 'To tame inflation'

COOKING: THE ECONOMIC MENU

Appetite: 'to curb the voracious appetites of speculators' (Business Week)

Ingredients/Recipe: 'Nations want to know the ingredients in a successful recipe'

(Samuelson)

Lunch: 'There is no such thing as a free lunch'

Menu: 'There is no free lunch on the monetarist menu' (Samuelson)

Pie: 'the economic pie', 'to divide/to cut the pie into equal slices'

\section{HEALTH/MEDICINE: THE ECONOMY NEEDS A DOCTOR}

Ailments/Contagious: 'To see why economic ailments can be contagious, let us examine the principle links in the interaction of nations' economic policies' (Samuelson)

Diagnosis/Remedies: 'Having considered the possible diagnoses, economics can also suggest possible remedies' (Samuelson)

Diagnose/Prescribe: 'The major task of macroeconomics today is to diagnose the condition of the economy and to prescribe the right medicine' (Samuelson)

Diet: 'The new diet may leave a bitter taste with investors' (Business Week)

Health/Healthy: 'Domestic economic welfare depends upon the health of the entire international economy'. (Samuelson) - 'Analysts [...] believe we'll be healthier in the long run' (Business Week)

Inject/Injection: ‘To inject some money into the economy [...] a monetary injection'. (Mankiw)

Malady: 'Poverty is an economic malady that affects all groups within the population, but it does not affect all groups with equal frequency'. (Mankiw)

Medicine/Administer: 'With inflation still at bay, there is no reason for the Fed to administer bitter monetary medicine'. (Business Week)

Painful/Pain: 'Macroeconomics examines the sources of such persistent and painful unemployment.' (Samuelson)

LIQUIDITY: THE ECONOMY IS A LIQUID ELEMENT

Drain from: 'Hence the fear that new companies will drain liquidity from traditional markets' (The Economist)

Drown: 'The bond market is drowning in a sea of new issues' (Business Week)

Dry up: 'Last autumn, when capital-market liquidity dried up, America's banks took up some of the slack (The Economist)

Flow: 'The flow of money is the lifeblood of our system' (Samuelson)

Liquid: 'Money is the most liquid asset' (Mankiw)

Mop up: Intervention by the bank failed to lower the yen, because it was 'sterilised' (through the bank mopping up liquidity in the money market' (The Economist) Pool: 'New companies [...] will divide big pools of liquidity into many smaller ones' (The Economist)

Pump into: 'After the 1987 stockmarket crash, central banks pumped liquidity into the financial system and economies continued to expand.' (The Economist)

MECHANISMS/AN ENGINE: THE ECONOMY IS A MACHINE

Fuel: 'A pronounced slowdown [...] would cut off the fuel for the New Economy growth- 
and-productivity machine.' (Business Week)

Gear: 'In an economy already running in high gear, the surge in petroleum prices certainly seems to spell trouble' (Business Week)

Grease/Oil: 'Inflation, the argument goes, greases the wheels of the labour market, allowing real wages to adjust more smoothly.' (The Economist)

Instruments: 'Also familiar are the policy instruments of government spending, taxes, and the money supply.' (Mankiw)

Lever: 'the monetary lever' (Greenspan)

Lubricant: 'Like other lubricants, money can get gummed up.' (Samuelson)

Ride/Engine/Wheels: 'The engine of economic progress must ride on four wheels [...] These four wheels are human resources, natural resources, capital formation and technology.'

(Samuelson)

Tools/Toolbox: 'The last tool in the Fed's toolbox is the discount rate...' (Mankiw)

MERGERS ARE UNIONS/MARRIAGES

Alliance: 'The friendly alliance is the latest in a series of consolidations within France's

borders...' (Financial Times)

Altar: 'to make it to the altar'

Bride: 'Marriage guidance for would-be brides' (The Economist)

Couplings: 'The hope behind such acquisitions is to mate the size of an elephant with the cunning of a fox. But such couplings are hard to pull off... (The Economist)

Flirt: 'Before throwing in its lot with Chase, Hambrecht had flirted with Merrill Lynch'

Liaison: 'Concert, progeny of the liaison between BT and MCI, offers global telecoms services.' (The Economist)

Love (a love match): 'It was never a love match.' (The Economist)

Marriage: 'The Carrefour-Promodès alliance is in part a marriage of convenience, designed to fend off any overtures from Wal-Mart, the world's biggest retailer.' (Time)

Suitor: 'Wal-Mart is a well-endowed and aggressive suitor.' (Time)

Tie the knot: 'Instead of tying the knot with an equally well-endowed partner such as

Merrill Lynch, the Wall Street giant has gone for a petite Californian investment-banking boutique.' (Business Week)

Union: 'Banks are moving towards union.' (The Economist)

Wedding invitations: 'The wedding invitations, full of breathless talk of global logic and energy, were echoed by starstruck analysts.' (The Economist)

Woo: 'to woo shareholders' (Time)

PLANE: THE ECONOMY IS A FLYING MACHINE

Altitude: 'The economy quickly regained altitude in 1996' (Business Week)

Cushion/Shocks: 'to cushion the economy against all shocks' (The Economist)

Landing (hard/soft): This time, Greenspan can anticipate a smoother ride. So will it be a soft landing?' (Business Week) - 'Britain's deficit proved to be unsustainable, causing the economy to suffer a hard landing once the bubble burst.' (The Economist) High-flying: 'High-flying stocks are spiraling back toward terra firma.' (Business Week)

Radar screens (to scan the horizon): 'Even at the Federal Reserve, when chairman Alan Greenspan scans the horizon for signs of inflation, oil prices barely appear on the radar screen'. (Business Week)

Seatbelts Taxi to the gate: 'Despite the daft economic management to date, remember to keep your seatbelts securely fastened until the economy taxis safely to the gate' (Business 
Week)

Touch-and-go landing: 'The Fed wound up doubling short-term interest rates in the space of a year. That produced more of a touch-and-go landing.' (Business Week)

SHIP: THE ECONOMY'S BOAT MUST BE STEERED TO A SAFE HAVEN

Compass/Maps: 'Central bankers [...] operate in a world of huge uncertainty, with no reliable maps or compasses.' (The Economist)

Crew: '[A major crisis could take place]. Fickle investors, consumers and businessmen might then see Mr Greenspan and his crew in a much less favourable light.' (The Economist )

Drift: 'The poverty rate has not declined and, in fact, has drifted upward to some extent.' (Mankiw)

Navigator: 'The best way for the navigators to stay afloat is to keep a wider watch for hazards at sea.' (The Economist)

Navigational skills: 'In this increasingly foggy world, the chances of navigational errors are high.' (The Economist)

Rough seas: 'Even in the shorter term, the seas ahead could get rougher.' (The Economist) Steer: 'Central bankers' ability to steer economies with precision is limited.' (The Economist )

Tide: 'Since the early 1970s, the economy's rising tide has left some boats behind.'

(Mankiw) - 'For most of American history, economic growth was a rising tide that lifted all boats, raising the incomes of the poor as well as those of the rich.' (Samuelson)

\section{SPEED: THE ECONOMY'S PACE MUST BE KEPT UNDER CONTROL}

Accelerate: 'inflation accelerates'

Brakes (to hit, to slam on, to tap, a tap): 'With the economy still going like a train, even the most fervent believer in the new economy would be hard pressed to mount a strong case against a gentle tap on the brakes.' (The Economist)

Hot-rod: 'The hot-rod economy' (Business Week)

Screech to a halt/Slow/Stall: 'The stock market has stalled [...] Slowing, not screeching to a halt. That's the scenario that Greenspan wants to play out.' (Business Week)

Speed limit: 'If American workers produce more per person, then the economy's safe speed limit rises.' (The Economist)

\section{TEMPERATURE: THE ECONOMY'S ENGINE NEEDS CHECKING}

Chill: 'An oil price rise chills the economy [...] Raising rates would exacerbate the chilling effect of costly oil.' (Business Week)

Cool: 'After all, the purpose of a rate hike is to cool an overheated economy.' (Business Week )

Overheat(ing): 'Greenspan wants to lead stock prices into a gentle landing before the supercharged market overheats the economy and strokes up inflation.' (Business Week) Hot: 'The economy is looking uncomfortably hot.' (The Wall Street Journal)

Red-hot: 'The economists expect consumer spending to cool off from its red-hot pace in 1999.' (The Wall Street Journal)

Sizzle: 'The economy continues to sizzle too furiously for its own good: higher rates are needed to cool things down.' (The Economist)

Appendix 2 
In the following network, the arrows point out the links between the metaphoric fields. The notions that have been circled are the ones that serve as nodes, from which various metaphors may branch out.

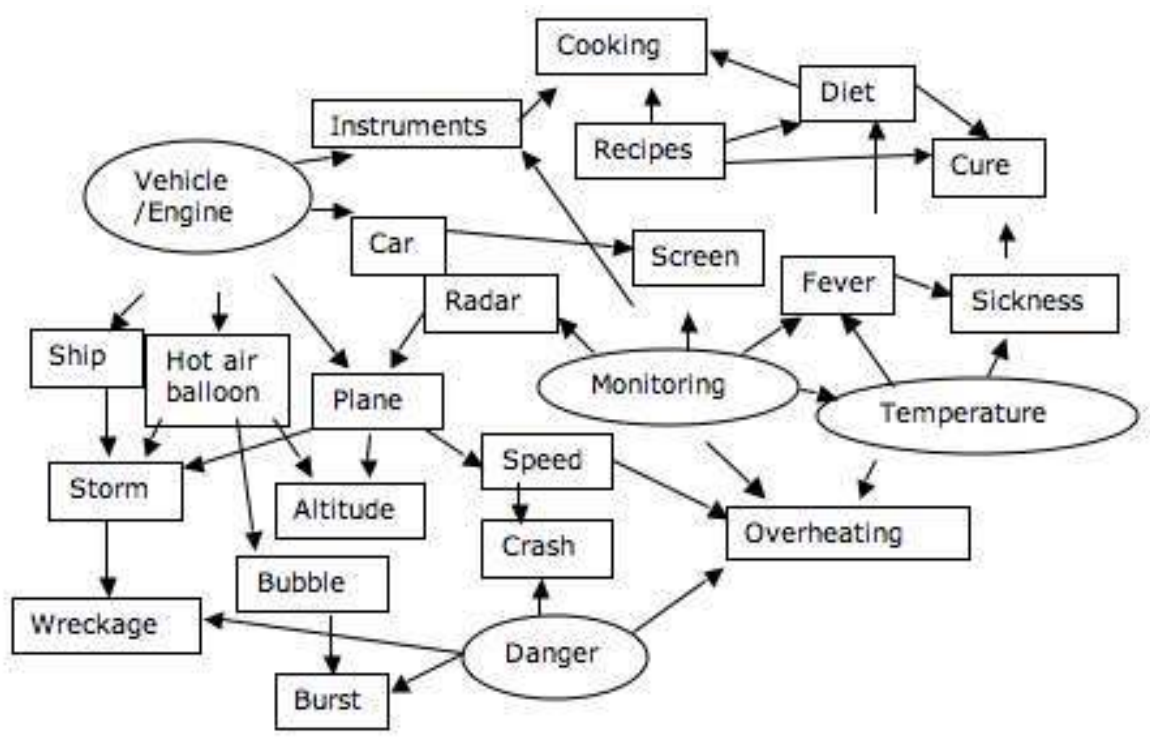

\section{ABSTRACTS}

Investigating English for economics also implies studying its metaphoric dimension. This paper focuses on the need for a language-based approach to metaphor within the framework of second language acquisition in the field of ESP. First, the functions and types of metaphors encountered in different sources of economic discourse are examined. The benefits derived from establishing not only notional but also lexical networks are then considered. Next the semantic and syntactic problems that require special attention are analysed in order to stress the numerous hurdles that L2 learners have to overcome to fully understand metaphors. Obviously the aim is not to encourage them to coin new metaphors or even to re-use extended metaphors. The limits of this approach are clearly stated: its goal is to help L2 learners to improve their understanding of metaphors and to be able to incorporate only the most current phrase metaphors in their own discourse in English on economic matters.

Étudier la langue économique en anglais implique de s'intéresser à toutes ses composantes, y compris la dimension métaphorique. Cette étude porte sur la nécessité d'une approche de la métaphore axée sur la langue étrangère dans un domaine spécialisé. Après avoir examiné les fonctions de la métaphore et les différents types de métaphores rencontrés dans des textes économiques, nous envisagerons l'intérêt de considérer non seulement les réseaux notionnels mais également les réseaux lexicaux. Les problèmes sémantiques et syntaxiques qui se posent tout particulièrement à un public étranger seront analysés. De toute évidence, il ne s'agit pas de prétendre amener les étudiants en économie à créer leurs propres métaphores, ni même à réutiliser les métaphores filées. Notre approche se limite à montrer comment, en revanche, on peut aider les apprenants à identifier, comprendre et s'approprier les métaphores les plus courantes qui font partie intégrante du discours économique. Le but ultime est qu'ils puissent s'exprimer de manière plus authentique en intégrant la dimension métaphorique à leur production écrite ou orale en anglais économique. 
INDEX

Keywords: applied linguistics, collocate, notional link, semantic relation, syntax, systematicity Mots-clés: co-occurrent, lien notionnel, linguistique appliquée, relation sémantique, syntaxe, système de champs métaphoriques

\section{AUTHOR}

\section{CATHERINE RESCHE}

Catherine Resche est maître de conférences HdR. Elle enseigne l'anglais économique et financier en troisième cycle et sa recherche est entièrement consacrée à la langue économique sous ses différents aspects: terminologie, phraséologie, néologie, métaphores, discours, genre. Elle est membre du Cerlac (Centre de Recherche en Langues spécialisées et Cultures) de l'université

Panthéon-Sorbonne - Paris 1. catherineresche@club-internet.fr 